doi: 10.52370/TISC21466SD

\title{
DETERMINING THE DIFFERENCES IN TOURIST'S RISK PERCEPTION AND TRAVEL INTENTION DURING COVID-19 HEALTH CRISIS: CASE STUDY OF SERBIA
}

\author{
Sandra Dramićanin ${ }^{1}$; Goran Perić ${ }^{2}$
}

\begin{abstract}
The research purpose is determination of the differences in Serbian tourist's perceived risk, during the COVID-19 health crisis, according to travel intention and destination of travel. In order to accomplish an analysis of differences between risks (travel risk, destination risk, health risk, financial risk), risk scores were calculated using confirmatory factor analysis (CFA). Testing the differences in relation to the travel intention and destination of travel during the COVID-19 pandemic according to risk perception was conducted through one-way MANOVA, where two models were applied. The outcome of the first model shows: significant impact of travel intention on a linear combination of risk factors. Also, taking into account all four risk factors, there are significant differences between those who intend to travel during a pandemic and those without that intention. In the second model, the findings indicate significant impact of the travel destination on a linear combination of risk factors, and significant differences between those respondents who intend to travel during the COVID-19 pandemic in the country and those respondents who intend to travel abroad according towards the perception of health risk, destination risk, and travel risk.
\end{abstract}

Key Words: COVID-19, perceived risk, travel intention, Serbia JEL classification: Z33; M31

\footnotetext{
${ }^{1}$ Sandra Dramićanin, MSc, PhD student, University of Kragujevac, Faculty of Hotel Management and Tourism, Vojvođanska bb, Vrnjačka Banja, Serbia, +381641566582, sandradramicanin@hotmalil.com

${ }^{2}$ Goran Perić, MSc, PhD student, Lecturer, Department of Business Studies Blace, Academy of Professional Studies South Serbia, Partizanska 7, Leskovac, Serbia, +38127371377, goran.peric@ vpskp.edu.rs
} 


\section{Introduction}

"SARS-CoV-2" (COVID-19), from the group of Coronaviruses, was identified on December $31^{\text {st }}$ in China (Wuhan) (Gossling et al., 2020). The existence of the virus was officially confirmed on January $30^{\text {th }}, 2020$, and the COVID-19 pandemic was declared two months later (Neuburger \& Egger, 2020). Due to the health crisis caused by the COVID-19 virus, travel has been reduced and limited worldwide. The COVID-19 health crisis has destroyed tourism industry around the world, due to the travel limitations forced by most countries (Li \& Ito, 2021). Tourism is certainly the most stricken sectors due the COVID-19 health crisis. The impact of COVID-19 on industry of travel is serious; it causes great negative consequences, even greater than during 2003-2004, caused by the SARS virus. There are currently 110,384,747 cases worldwide where the presence of the COVID19 virus has been diagnosed and a total of 2,456,008 deaths (World Health Organization, 2021). Countries are taking drastic measures to control the pandemic that has befallen the whole world (Ugur \& Akbiyik, 2020).

Epidemics and pandemics are unfavorable for travelers and those planning trips because they bring with them different types of risks and potential risk situations. In addition, not only passengers are at risk, but also other people they come in contact with during the trip (Bae \& Chang, 2020). Passengers affect a serious role in the transmission of the COVID-19 virus between destination and place of residence. Constant information regarding the risks at the destination is considered a good starting point for assessing and changing travel plans of potential travelers, as well as for revealing forecasts related to the recovery of the tourism industry (Gossling et al., 2020). The purpose of informing about risks is to make clear, instruct or advise potential passengers of possible critical situations that may befall them at the destination.

In leisure industry and travel business, COVID-19 health crisis has caused serious economic losses. Safety and the reduction of all types of travel risks are key matters when travelers make travel decisions (Saadat et al., 2020). The literature offers various studies related to risks in tourism (Leonard et al., 2020; Perić et al., 2021; Ritchie \& Jiang, 2019; Yi et al. 2020). Most studies present passenger concerns and destination-related risks. Passengers' fear was especially pronounced during the COVID-19 health crisis (Qiu et al., 2020). Fear and risk directly affect passengers' travel behavior. The COVID-19 health crisis has turned the way people live. The pandemic has particularly affected the changing preferences related to 
tourism (Lee et al., 2020). There are numerous studies that have explored the influence of perceived risk on intentions, also behavior of tourists ongoing COVID-19 health crisis (Abraham et al., 2020; Li \& Ito, 2021; Neuburger \& Egger, 2020; Perić et al., 2021), but there are no studies examining differences in risk perception and travel intention during a COVID-19 health crisis. Accordingly, the study purpose is to determine the differences in Serbian tourist's perceived risk during the COVID-19 health crisis (travel intention and destination).

\section{Impact of COVID-19 on tourism in Serbia}

Currently, there are 434,122 confirmed COVID-19 cases and 4,321 confirmed COVID-19 deaths in the Republic of Serbia (Ministry of Health of the Republic of Serbia, 2021). At this moment, preventive measures are still valid on the territory of the Republic of Serbia. The goal is to reduce the risk of the appearance of COVID-19 and the transmission of this virus among the population (Ministry of Health of the Republic of Serbia, 2021).

The COVID-19 health crisis is an extraordinary global crisis that has a huge impact on worldwide tourism industry (Matiza, 2020). The COVID-19 health crisis has hit tourism sector in the Republic of Serbia, and this part of economic activity is suffering huge losses (Perić et al, 2021). At its peak, when the borders around the world are closed, it is noticed that the losses will be enormous and that the recovery of the tourism sector will not start so quickly. It is still unknown how long the world will fight the COVID19 virus. The COVID-19 health crisis is different from all previous ones and the recovery will take longer than predictable recovery time (10 months) (Škare et al., 2020).

The global travel and leisure industry has been the first to be quite negatively affected by the pandemic, as passengers have given up traveling due to increased risk (Sigala, 2020). Tourism is affecting the spread of the epidemic around the world due to the great mobility of passengers, and the epidemic is also affecting tourism (Madanoglu \& Ozdemir, 2018). Strict ban on international tourism, minimal restrictions on domestic travel, have made domestic tourism the only acceptable and sustainable choice for travelers (Hotle \& Mumbower, 2021). The situation with the Republic of Serbia is the same. However, the number of tourists in 2020 compared to 2019 shows a drastic reduction in the number of arrivals and overnight stays. Only in December 2020, compared to December 2019, did the number of tourist arrivals decrease by $67.1 \%$, and the number of overnight 
stays decrease by 59.9\%. In December 2020, compared to December 2019, the number of overnight stays of domestic tourists decreased by $46.7 \%$, and the number of overnight stays of foreign tourists decreased by $75.6 \%$ (Statistical Office of the Republic of Serbia, 2021).

\section{Perceived risk in tourism}

Currently, major changes are happening in the world, and they are related to the safety aspect of travel, so the absence of risk is becoming one of the most important criteria when choosing a destination. Risk perception is a dynamic concept (Neuburger \& Egger, 2020). The perception of risk mostly depends on the characteristics of the travelers and theirs desires, needs and understanding of the world around them. Risk perception is the nature and amount of risk that travelers perceive when considering and making a choice regarding a particular purchase or choice of tourist destination for travel (Cox \& Rich, 1964). Haddock (1993) describes perceived risk as a subjective evaluation of potential threats and hazards, with the existence of security controls. Reid and Ritchie (2011) present perceived risk as an effect of uncertainty that could affect financial, social, environmental, health, and other aspects of security.

The existing literature considers security risk as the most important and the risk that influences the tourist's decision about the travel destination the most (Artuger, 2015; Aqueveque, 2006; Bagarić et al., 2019; Kim et al., 2019). There is a lot of research dealing with influences on the tourist's decision to choose a travel destination (Dramićanin \& Sančanin, 2020), however, the effects of risk perception that can be experienced during travel have not been sufficiently investigated (Adeloye \& Brown, 2018). Although risk perception is most often studied in the context of international travel, it also varies depending on the destination of the trip (Sonmez \& Graefe, 1998).

Reisinger and Mavondo (2006) define tourism risk as a perceived risk during the process of purchasing and consuming tourism services. These authors quote five main risks: violence, warfare and political insecurity, health risks, crime, and cultural and linguistic difficulties.

Everyday measures, including the current COVID-19 health crisis, suggest that global risks, including risks in the Republic of Serbia, do not tend to reduce or disappear altogether. In such situations, risk prevention is a standard that is important to potential travelers, so ensuring that the 
destination is risk-free for passengers becomes a significant competitive advantage (Ling Yang \& Nair, 2014).

\section{COVID-19 health crisis: perceived risk and travel intention}

The perception of risk is related to the tourist awareness of insecurity and potential unpleasant outcomes that arise from going on a trip and using tourist services (Adam, 2015). Previous research has explored the products of risk perception in a tourism context and has resulted in risk as a multidimensional concept (Cui et al., 2015).

Predictions show that the impact of the COVID-19 virus on world tourism will be remarkable (Nicola et al., 2020). The situation in the Republic of Serbia, as far as travel is concerned, is the same as in the world. A large number of flights to and from Serbia have been canceled. The turnover in travel agencies during 2020 dropped by up to $90 \%$ compared to 2019 . The largest number of tourists travels around and in Serbia, although the recorded tourist traffic is lower than in the previous year. To reduce the risk of travel, passengers are advised to travel by their own transport (car) or travel by plane with as few transfers as possible. Different countries have different measures to struggle with the pandemic of the COVID-19 virus, so travelers from the Republic of Serbia depends on the further development of the situation with the COVID-19 health crisis. The COVID-19 health crisis in the Republic of Serbia depends on the further development of the situation with the COVID-19 virus pandemic. The pandemic in the Republic of Serbia has not only changed the choice of travel destination, but also the type and manner in which passengers will travel. The COVID-19 health crisis has complicated the movement of people in the Republic of Serbia, and travel restrictions have been introduced in order to preserve health and reduce risks and prevent the spread of the virus. Travel is more difficult and less frequent. Due to various restrictions, such as the need for passengers to be tested before traveling, but also due to the fear of different types of risks at the travel destination, most do not travel or travel as much as necessary.

Destinations, such as the Republic of Serbia, want to restart tourism for economic survival (Valeri \& Baggio, 2020). The quality of the destination and risk avoidance is an important element for the loyalty and re-visits of tourists (Perić et al., 2020) because in tourism the satisfaction of tourists relies on their experience during the trip (Perić et al., 2018). Due to the future of the global tourism industry, the effect of the pandemic on travel 
and tourism is particularly worrying. Even after the end of the COVID-19 health crisis, the perceived risk is associated with travel (Wang et al., 2020). Although there is a connection among the risk perception and travel intention in the modern post-COVID-19 time on the global tourist market, it is necessary to investigate this connection. Preliminary economic research and modeling suggest that there is a significant inverse link among the COVID-19 health crisis and tourist demand, and the desire of travelers to visit a destination (Yanga et al., 2020). It is necessary to investigate the impact of the current COVID-19 health crisis on perceived risk. And even more significant is research on how risk perception affects travelers and their behavior and desire to travel (Matiza, 2020). The unique nature of the COVID-19 health crisis negatively affects psychological and social risk. This suggests that risk perception is precursor to consumer decisionmaking in tourism and multidimensional and dynamic concept, subject to internal and external forces, such as the COVID-19 health crisis (Perić et al., 2021; Zhu \& Deng, 2020).

Numerous studies have examined perceptual risk during various health crises around the world (Cahyanto et al., 2016). The influence of perception risk on travel decision appears to be more obvious than the impact of risk on material purchasing decisions. Perceived risk is a precursor in the decision-making process of tourists and the critical dimension, among other things due to their cognitive and affective behavior, and the existence of travel intention (Osland et al., 2017). Perceived risk is largely connected to the intention to change the travel plan, travel or avoid a certain destination (Schroeder et al., 2013). Higher risk perceptions may lead to a higher probability of changing the travel date or avoiding travel altogether (Pennington-Gray et al., 2011). The increased risk perception of travel during COVID-19 health crisis is reliable with earlier studies on infectious disease outbreaks (Joo et al., 2021; Li \& Ito, 2021; Chemli et al., 2020; Gossling et al., 2020). Nevertheless, the COVID-19 health crisis overcomes previous tourism crises and over time affects passenger risk perception and passenger behavior (Neuburger \& Egger, 2020).

\section{Methodology}

The research was conducted during December 2020, through an online questionnaire (distributed through the Facebook and Twitter). The total number of respondents is 338 . These subjects were included in the research, and the basic characteristics of the sample are given in the following table. 
Table 1: Basic sample estimates

\begin{tabular}{lcc}
\hline & \multicolumn{2}{c}{$N=338$} \\
\cline { 2 - 3 } & $\mathrm{N}$ & $\%$ \\
\hline Gender & 237 & 70.1 \\
Female & 101 & 29.9 \\
Male & & \\
Level of education & 60 & 17.8 \\
$\quad$ High school & 59 & 17.5 \\
Applied degree & 134 & 39.6 \\
Academic degree & 85 & 25.1 \\
Master/PhD & & \\
Monthly income & 55 & 16.3 \\
To 246 $€$ & 126 & 37.3 \\
From 247 to 510 $€$ & 110 & 32.5 \\
From 511 to 765 $€$ & 47 & 13.9 \\
Over 765 $€$ & & \\
Intention to travel & 80 & 23.7 \\
$\quad$ No & 258 & 76.3 \\
$\quad$ Yes & & \\
Destination & 145 & 56.2 \\
In the country & 113 & 43.8 \\
$\quad$ Abroad & M & SD \\
\hline Age & 39.89 & 10.89 \\
\hline
\end{tabular}

Source: Author's calculation

In the simple, women have the largest share of 237 (70.1\%), and most respondents have academic education - 134 (39.6\%). The majority of respondents $(69.8 \%)$ have a monthly income of 247 to $765 €$. The respondents are on average middle-aged $(\mathrm{M}=39.89 ; \mathrm{SD}=10.90)$. Of the 258 respondents who would travel during the COVID-19 heath crisis, 145 $(56.2 \%)$ would travel in the country. The questionnaire (Perić et al., 2021) was used to measure the perceived risk factors (travel risk, destination risk, health risk, and financial risk) and contains 24 questions (see Appendix). Respondents used a five-point Likert scale, and score risk factors were calculated using confirmatory factor analysis. To test the differences in risk perception in relation to the intention and destination of the trip, one-way MANOVA was used, where two models were applied. The independent variable is travel intention which is dichotomous and operationalized by the question: "Will you travel during the COVID-19 pandemic?" The dependent variables in the first model are travel risk, destination risk, health, and financial risk. The second model is an independent travel 
destination variable and is operationalized using the question: "Where will you travel?" The independent variable is dichotomous with possible answers: "in the country" and "abroad". The dependent variables are the same as in the first model.

\section{Data analysis and results}

The analysis starts from a confirmatory factor analysis (CFA) which is used to calculate risk factor scores. Five questions (Q8, Q13, Q14, Q15 and Q17) were recorded, the meaning of which was reversed in relation to the other questions. After setting up the initial model, four questions were identified (Q6, Q8, Q10 and Q11) whose coefficients of explanation of variance by the corresponding factor are below the acceptability limit of 0.4 . The results are shown in the following table:

Table 2: CFA and reliability

\begin{tabular}{lcccc}
\hline \multicolumn{1}{c}{ Questions/Risks } & Loading & $\boldsymbol{\alpha}$ & CR & AVE \\
\hline Travel risk & & 0.840 & 0.844 & 0.523 \\
Q1 & 0.735 & & & \\
Q2 & 0.800 & & & \\
Q3 & 0.806 & & & \\
Q4 & 0.638 & & & \\
Q5 & 0.615 & & & \\
Destination risk & & 0.783 & 0.803 & 0.586 \\
Q7 & 0.827 & & & \\
Q9 & 0.888 & & & \\
Q12 & 0.534 & & & \\
Health risk & & 0.905 & 0.905 & 0.545 \\
Q13 & 0.808 & & & \\
Q14 & 0.776 & & & \\
Q15 & 0.822 & & & \\
Q16 & 0.722 & & & \\
Q17 & 0.715 & & & \\
Q18 & 0.736 & & & \\
Q19 & 0.664 & & & \\
Q20 & 0,644 & & & \\
Financial risk & & 0.868 & 0.869 & 0.626 \\
Q21 & 0.722 & & & \\
Q22 & 0.782 & & & \\
Q23 & 0.855 & & & \\
Q24 & 0.799 & & &
\end{tabular}

Source: Author's calculation by AMOS 21 
Most of the coefficients are above 0.7 and all are statistically significant, which indicates that those issues that are highly correlated with the risk factor are retained in the model. The reliability of all factors is good (Cronbach $\alpha>0.07$ ), composite reliability (CR) for all factors is above the recommended suggested minimum of 0.70 , while the average explanation of variance (AVE) ranges from 0.52 to 0.63 which is above the recommended minimum. These data indicate that all factors have good internal consistency and reliability.

When testing the differences in perceived risk in relation to the travel intention, the preconditions for the use of one-way MANOVA were preliminarily tested: normality, presence of extreme values, multicollinearity, singularity and homogeneity of variance-covariance matrices. No major breach of assumptions was observed. The outcome show: significant effect of travel intention on the linear combination of risk factors $(F(4.329)=14.84 ; p=0.00$; Pillai's Trace $=0.15$; partial $\eta 2=0.15)$. When perceived risk factors are observed individually, there are significant differences with Bonferroni adjusted between respondents intending to travel during a COVID-19 health crisis and respondents who will not.

Table 3: Results of MANOVA - travel intention

\begin{tabular}{|c|c|c|c|c|c|c|}
\hline $\begin{array}{c}\text { Risk } \\
\text { perception }\end{array}$ & $\mathbf{F}$ & $p$ & $\begin{array}{c}\text { Partial } \\
\eta^{2}\end{array}$ & $\begin{array}{c}\text { Travel } \\
\text { intention }\end{array}$ & $\mathbf{M}$ & SD \\
\hline \multirow{2}{*}{ Health risk } & \multirow{2}{*}{14.41} & \multirow{2}{*}{0.00} & \multirow{2}{*}{0.04} & No & 0.29 & 0.63 \\
\hline & & & & Yes & -0.08 & 0.78 \\
\hline \multirow{2}{*}{$\begin{array}{l}\text { Destination } \\
\text { risk }\end{array}$} & \multirow{2}{*}{7.89} & \multirow{2}{*}{0.00} & \multirow{2}{*}{0.02} & No & 0.26 & 0.86 \\
\hline & & & & Yes & -0.08 & 0.95 \\
\hline \multirow{2}{*}{ Travel risk } & \multirow{2}{*}{33.13} & \multirow{2}{*}{0.00} & \multirow{2}{*}{0.09} & No & 0.51 & 0.73 \\
\hline & & & & Yes & -0.13 & 0.98 \\
\hline \multirow{2}{*}{$\begin{array}{l}\text { Financial } \\
\text { risk }\end{array}$} & \multirow{2}{*}{18.36} & \multirow{2}{*}{0.00} & \multirow{2}{*}{0.05} & No & 0.33 & 0.88 \\
\hline & & & & Yes & -0.12 & 0.80 \\
\hline
\end{tabular}

Source: Author's calculation by SPSS 26

The results shown in the previous table indicate that tourists who do not intend to travel rate perceived risk factors higher (health risk, destination risk, travel and financial risk) compared to tourists who intent to travel during the COVID-19 health crisis.

To test the differences in perceived risk in relation to the destination, between travel in the country and abroad, only respondents who expressed their intention to travel during the period of the COVID-19 health crisis 
were included $(\mathrm{N}=258)$. Also, the assumptions for the use of one-way MANOVA were tested and no major violation of the assumptions was observed. In this model, too, there is a significant effect of the travel destination on the linear combination of risk factors $(\mathrm{F}(4.252)=4.44 ; \mathrm{p}=$ 0.00 ; Wilks' Lambda $=0.93$; partial $\eta 2=0.07$ ). The results presented in Table 4 indicate that when dependent variables are observed individually, there are significant Bonferroni adjusted differences between respondents who intend to travel during a pandemic in the country and respondents who intend to travel abroad according to health risk perception, destination risk and travel risk.

Table 4: Results of MANOVA - destination

\begin{tabular}{|c|c|c|c|c|c|c|}
\hline $\begin{array}{c}\text { Risk } \\
\text { perception }\end{array}$ & $\mathbf{F}$ & $p$ & $\begin{array}{c}\text { Partial } \\
\eta^{2}\end{array}$ & Destination & $\mathbf{M}$ & SD \\
\hline \multirow{2}{*}{ Health risk } & \multirow{2}{*}{14.15} & \multirow{2}{*}{0.00} & \multirow{2}{*}{0.05} & In the country & 0.08 & 0.74 \\
\hline & & & & Abroad & -0.28 & 0.79 \\
\hline \multirow{2}{*}{$\begin{array}{l}\text { Destination } \\
\text { risk }\end{array}$} & \multirow{2}{*}{6.53} & \multirow{2}{*}{0.01} & \multirow{2}{*}{0.03} & In the country & -0.21 & 0.88 \\
\hline & & & & Abroad & 0.09 & 1.02 \\
\hline \multirow{2}{*}{ Travel risk } & \multirow{2}{*}{11.87} & \multirow{2}{*}{0.00} & \multirow{2}{*}{0.04} & In the country & 0.03 & 0.88 \\
\hline & & & & Abroad & -0.35 & 0.86 \\
\hline \multirow{2}{*}{$\begin{array}{l}\text { Financial } \\
\text { risk }\end{array}$} & \multirow{2}{*}{1.83} & \multirow{2}{*}{0.09} & \multirow{2}{*}{0.01} & In the country & -0.05 & 0.79 \\
\hline & & & & Abroad & -0.22 & 0.79 \\
\hline
\end{tabular}

Source: Author's calculation by SPSS 26

Tourists who intent to travel in the country assess a higher health risk compared to tourists who intent to travel abroad. Tourists planning to travel in the country estimate the destination risk lower than those intending to travel abroad during the COVID-19 health crisis. The results indicate that tourists who intent to travel in the country assess a higher travel risk compared to those who intent to travel abroad during the current health crisis. When it comes to financial risk, the results indicate that there are no statistically significant differences.

\section{Discussion and conclusions}

This study explored the differences between tourists intend to travel during the COVID-19 health crisis and tourists who do not intend to travel according to the perception of risk factors. One-way MANOVA findings show that there are statistically significant differences in risk perception between tourists who intend to travel during a pandemic and tourists who do not intend to travel during a COVID-19 health crisis, or a group of 
tourists who do not intend to travel to a higher health risk, destinations risk, travel risk and financial risk. This result is in line with a study conducted in May 2020 in Serbia, the results suggest that improving risk reduces the chances of traveling during the COVID-19 health crisis (Perić et al., 2021). Other studies investigating perceived risk and travel intentions have confirmed that risk perception is essential for travel decision making (Agyeiwaah et al., 2021; Falahuddin et al., 2020; Li \& Ito, 2021; Zhan et al., 2020). When it comes to the differences between travel in the country and abroad in terms of risk perception, the findings indicate significant differences in terms of health risk, destination risk and travel risk. Therefore, tourists who intend to travel in the country assess a higher health risk compared to tourists who intend to travel abroad. The result shows that tourists perceive health risk as lower abroad; those tourists are prepared to take a higher risk, which is in agreement with the results of other studies (Aro et al., 2009; Perić et al., 2021). Tourists who intend to travel in the country estimate a lower risk of the destination compared to tourists who intent to travel abroad during the COVID-19 health crisis. During the pandemic, trips are mainly focused on the domestic tourism market because tourists believe that they can control the risk in the country and in these situations prefer traveling to natural areas (Perić et al., 2021). The literature says that a higher destination risk is associated with a lower probability of travel (Lee et al., 2012; Sridhar et al., 2016). The findings indicate a higher risk of travel for tourists who intend to travel in the country compared to those who intend to travel abroad during the COVID-19 health crisis, and a study conducted in Serbia, led to the opposite results, findings suggest that increasing the risk assessment reduces the chance of traveling abroad during the COVID-19 health crisis (Perić et al., 2021).

The purpose of this study has been achieved. There are statistically significant differences in risk perception between Serbian tourists according to the intention and destination of travel during the COVID-19 health crisis. Studying the perception of tourist risk in situations such as the COVID-19 health crisis is very important for understanding the attitudes and behavior of tourists in such situations. Without understanding the impact of risk perception on travel intentions and tourist behavior, strategies used to moderate risk and attract potential tourists will not be effective. It is especially important for the destination management in the country to work on formulating a strategy for justifying health risk, having in mind the findings of research, it is necessary to take into relation high hygiene standards and health safety of potential tourists. The research outcome suggest that tourist flows during the COVID-19 health crisis will 
be mainly directed to domestic destinations, and that travel will be conducted with great caution. Therefore, destination management and marketing should develop strategies to attract domestic tourists, primarily as a short-term measure to recover sector in the country, and this study provides them with insight into the importance of risk perception of travel intentions, as well as the ability to see current COVID-19 health crisis trends.

\section{References}

1. Abraham, V., Bremser, K., Carreno, M., Crowley-Cyr, L., Moreno, M. (2020). Exploring the consequences of COVID-19 on tourist behaviors: perceived travel risk, animosity and intentions to travel. Tourism Review.

2. Adam, I. (2015). Backpackers' risk perceptions and risk reduction strategies in Ghana, Tourism Management, Vol. 49, 99-108.

3. Adeloye, D., Brown, L. (2018). Terrorism and domestic tourist risk perceptions. Journal of Tourism and Cultural Change, Vol. 16, 217-233.

4. Agyeiwaah, E., Issahaku, A., Dayour, F., Badu Baiden, F. (2021). Perceived impacts of COVID-19 on risk perceptions, emotions, and travel intentions: evidence from Macau higher educational institutions. Tourism Recreation Research, 1-17.

5. Aqueveque, C. (2006). Extrinsic cues and perceived risk: The influence of consumption situation. Journal of Consumer Marketing, Vol. 23, No. 5, 237-247.

6. Aro, A. R., Vartti, A. M., Schreck, M., Turtiainen, P., Uutela, A. (2009). Willingness to take travel-related health risks-A study among Finnish tourists in Asia during the avian influenza outbreak. International journal of behavioral medicine, Vol. 16, No. 1, 68-79.

7. Artuger, S. (2015). The Effect of Risk Perceptions on Tourists' Revisit Intentions. European Journal of Business and Management, Vol. 7, No. 2, 36-43.

8. Bae, S. Y., Chang, P. J. (2020). The effect of coronavirus disease-19 (COVID-19) risk perception on behavioural intention towards 'untact' 
tourism in South Korea during the first wave of the pandemic. Current Issues in Tourism, 1-19.

9. Bagarić, L., Barišić, M., Kuran Martić, L. (2019). Značaj percepcije osobne sigurnosti u turističkoj destinaciji s aspekta mladih turista. Zbornik Veleučilišta u Rijeci, Vol. 7, No. 1, 209-221.

10. Cahyanto, I., Wiblishauser, M., Pennington-Gray, L., Schroeder, A. (2016). The dynamics of travel avoidance: The case of Ebola in the US. Tourism Management Perspectives, Vol. 20, 195-203.

11. Chemli, S., Toanoglou, M., Valeri, M. (2020). The impact of Covid-19 media coverage on tourist's awareness for future travelling. Current Issues in Tourism, 1-8.

12. Cox, D.F., Rich, S.U. (1964). Perceived risk and consumer decisionmaking: The case of telephone shopping. Journal of Marketing Research, Vol. 1, No. 4, 32-39.

13. Cui, F., Liu, Y., Chang, Y., Duan, J. Li, J. (2016). An overview of tourism risk perception, Natural Hazards, Vol. 82, No. 1, 643-658.

14. Dramićanin, S., Sančanin, B. (2020). Influence of internet content on tourists decision to visit a cultural tourism destination. Bizinfo (Blace), Vol. 11, No. 2, 1-17.

15. Falahuddin, A. F., Tergu, C. T., Brollo, R., Nanda, R. O. (2020). Post COVID-19 Pandemic International Travel: Does Risk Perception and Stress-Level Affect Future Travel Intention?. Jurnal Ilmu Sosial dan Ilmu Politik, Vol. 24, No. 1, 1-14.

16. Gossling, S., Scott, D., Hall, C. M. (2020). Pandemics, tourism and global change: a rapid assessment of COVID-19. Journal of Sustainable Tourism, Vol. 29, No. 1, 1-20.

17. Haddock, C. (1993). Managing Risks in Outdoor Activities. New Zealand Mountain Safety Council, Wellington.

18. Hotle, S., Mumbower, S. (2021). The Impact of COVID-19 on Domestic U.S. Air Travel Operations and Commercial Airport Service. Transportation Research Interdisciplinary Perspectives, Vol. 9, 100277. 
19. Joo, D., Xu, W., Lee, J., Lee, C.K., Woosnam, K.M. (2021). Residents' perceived risk, emotional solidarity, and support for tourism amidst the COVID-19 pandemic. Journal of Destination Marketing \& Management, Vol. 19, 100553.

20. Kim, M. J., Bonn, M., Lee, C.K. (2019). The effects of motivation, deterrents, trust, and risk on tourism crowdfunding behavior The effects of motivation, deterrents, trust, and risk on tourism crowdfunding behavior. Asia Pacific Journal of Tourism Research, Vol. 25, 244-260.

21. Lee, C. K., Song, H. J., Bendle, L. J., Kim, M. J., Han, H. (2012). The impact of non-pharmaceutical interventions for 2009 H1N1 influenza on travel intentions: A model of goal-directed behavior. Tourism management, Vol. 33, No.1, 89-99.

22. Lee, C.C., Chen, M.P. (2020). Happiness sentiments and the prediction of cross-border country exchange-traded fund returns. The North American Journal of Economics and Finance, Vol. 54, 101254.

23. Leonard, L., Musavengane, R., Siakwah, P. (2020). Urban risk and tourism in Africa. Sustainable Urban Tourism in Sub-Saharan Africa: Risk and Resilience, 1-14.

24. Li, S. R., Ito, N. (2021). Nothing Can Stop Me! Perceived Risk and Travel Intention Amid the COVID-19 Pandemic: A Comparative Study of Wuhan and Sapporo. In Information and Communication Technologies in Tourism 2021 (490-503). Springer, Cham.

25. Ling Yang, C., Nair, V. (2014). Risk perception study in tourism: Are we really measuring perceived risk?. Procedia- Social and Behavioral Sciences, Vol. 144, 322-327.

26. Madanoglu, M., Ozdemir, O. (2018). Economic Policy Uncertainty and Hotel Operating Performance. Tourism Management, Vol. 71, 443-452.

27. Matiza, T. (2020). Post-COVID-19 crisis travel behavior: towards mitigating the effects of perceived risk. Journal of Tourism Futures. Vol. 6, No. 2, 1-14.

28. Ministry of Health of the Republic of Serbia. Korona virus COVID-19, https://covid19.rs/ (20 February 2021). 
29. Neuburger, L., Egger, R. (2020). Travel risk perception and travel behavior during the COVID-19 pandemic 2020: a case study of the DACH region. Current Issues in Tourism, 1-14.

30. Nicola, M., Alsafi, Z., Sohrabi, C., Kerwan, A., Al-Jabir, A., Iosifidis, C., Agha, M., Agha, R. (2020). The socio-economic implications of the coronavirus and COVID-19 pandemic: a review, International Journal of Surgery, Vol. 78, 185-193.

31. Osland, G.E., Mackoy, R., McCormick, M. (2017). Perceptions of personal risk in tourists' destination choices: nature tours in Mexico, European Journal of Tourism, Hospitality and Recreation, Vol. 8, No. 1, $38-50$.

32. Pennington-Gray, L., Schroeder, A., Kaplanidou, K. K. (2011). Examining the influence of past travel experience, general web searching behaviour and risk perception on future travel intentions. International Journal of Safety and Security in Tourism, Vol 1, No. 1, 64-92.

33. Perić, G., Dramićanin, S., Conić, M. (2021). The impact of Serbian tourists' risk perception on their travel intentions during the COVID-19 pandemic. European Journal of Tourism Research, Vol. 27, 2705.

34. Perić, G., Dramićanin, S., Gašić, M. (2020). Impact of service quality on satisfaction and loyalty of tourists in rural tourism of Šumadija and Western Serbia. Economics of Agriculture, Vol. 67, No. 4, 1071-1086.

35. Perić, G., Gašić, M., Stojiljković, M., Nešić, I. (2018). The impact of employee satisfaction on the tourist satisfaction with the services of spa tourism. Economics of Agriculture, Vol. 65, No.2, 617-632.

36. Qiu, R. T., Park, J., Li, S., Song, H. (2020). Social costs of tourism during the COVID-19 pandemic. Annals of Tourism Research, Vol. 84, 102994.

37. Reid, S., Ritchie, B. (2011). Risk management: Event managers' attitudes, beliefs, and perceived constraints. Event Management, Vol. 15, No. 4, 329-341.

38. Reisinger, Y., Mavondo, F. (2006). Cultural Differences in Travel Risk Perception, Journal of Travel \& Tourism Marketing, Vol. 20, No. 1, 13-31. 
39. Ritchie, B. W., \& Jiang, Y. (2019). A review of research on tourism risk, crisis and disaster management: Launching the annals of tourism research curated collection on tourism risk, crisis and disaster management. Annals of Tourism Research, Vol. 79, 102812.

40. Saadat, S, Rawtani, D, Hussain, C.M. (2020). Environmental perspective of COVID-19. Science of the Total Environment, Vol. 728, 138870.

41. Schroeder, A., Pennington-Gray, L., Kaplanidou, K., Zhan, F. (2013). Destination risk perceptions among U.S. Residents for London as the host city of the 2012 Summer Olympic Games. Tourism Management, Vol. 38, 107-119.

42. Sigala, M. (2020). Tourism and COVID-19: Impacts and implications for advancing and resetting industry and research. Journal of business research, Vol. 117, 312-321.

43. Sonmez, S., Graefe, A. (1998). Determining Future Travel Behavior from Past Travel Experience and Perceptions of Risk and Safety. Journal of Travel Research, Vol. 37, 171-177.

44. Sridhar, S., Régner, I., Brouqui, P., Gautret, P. (2016). Methodologies for measuring travelers' risk perception of infectious diseases: A systematic review. Travel Medicine and Infectious Disease, Vol. 14, No. 4, 360-372.

45. Statistical Office of the Republic of Serbia. (2021). Statistical release. Catering and Tourism Statistics, Number 24 - Year LXXI, 29.01.2021, 15.

46. Škare, M., Riberio Soriano, D., Porada-Rachon, M. (2020). Impact of COVID-19 on the travel and tourism industry. Technological Forecasting \& Social Change, Vol. 163. 124069.

47. Ugur, N. G., Akbiyık, A. (2020). Impacts of COVID-19 on global tourism industry: A cross-regional comparison. Tourism management perspectives, Vol. 36, 100744.

48. Valeri, M., Baggio, R. (2020). Italian tourism intermediaries: A social network analysis exploration. Current Issues in Tourism, 1-14. 
49. Wang, F., Xue, T., Wang, T., Wu, B. (2020). The Mechanism of Tourism Risk Perception in Severe Epidemic-The Antecedent Effect of Place Image Depicted in Anti-Epidemic Music Videos and the Moderating Effect of Visiting History. Sustainability, Vol. 12, No. 13, 5454.

50. World Health Organazation. Coronavirus Disease (COVID-2019) Situation Reports, https://www.who.int/emergencies/diseases/novelcoronavirus-2019/situation-reports (20 February 2021).

51. Yang, Y., Zhang, H., Chen, X. (2020). Coronavirus pandemic and tourism: dynamic stochastic general equilibrium modelling of infectious disease outbreak, Annals of Tourism Research, Vol. 83, 102913.

52. Yi, J., Yuan, G., Yoo, C. (2020). The effect of the perceived risk on the adoption of the sharing economy in the tourism industry: The case of Airbnb. Information Processing \& Management, Vol. 57, No. 1, 102108.

53. Zhan, L., Zeng, X., Morrison, A. M., Liang, H., Coca-Stefaniak, J. A. (2020). A risk perception scale for travel to a crisis epicentre: Visiting Wuhan after COVID-19. Current Issues in Tourism, 1-18.

54. Zhu, H., Deng, F. (2020). How to Influence Rural Tourism Intention by Risk Knowledge during COVID-19 Containment in China: Mediating Role of Risk Perception and Attitude. International Journal of Environmental Research and Public Health, Vol. 17, No. 10, 3514.

\section{Appendix: Questionnaire}

\begin{tabular}{cl}
\hline Q & \\
\hline Q1 & I don't feel comfortable if I have to travel now. \\
Q2 & It is risky to travel now. \\
Q3 & Due to COVID-19, I will avoid traveling in organized groups. \\
Q4 & Due to COVID-19, I will use only my own transport for the trip. \\
Q5 & Due to COVID-19, I will not use air transport for travel. \\
Q6 & I feel it would be very comfortable to travel now. \\
Q7 & Traveling to natural areas like national park is not risky. \\
Q8 & I will take care about number of COVID-19 cases, when I choose \\
Q9 & Excursions to natural areas is not risky. \\
Q10 & Visits to museums and other tourist attractions are not risky. \\
Q11 & Visits to swimming pools and other water attractions are not risky. \\
Q12 & Traveling near the place of residence is not risky.
\end{tabular}


Q13 Health safety is an important attribute that a destination can offer.

Q14 I take care of hygiene in the accommodation facilities.

Q15 Special attention should be paid to the health system when choosing a destination.

Q16 I am worried that the epidemiological situation in the destination could

worsen during the trip.

Q17 When traveling, it is important to have good health (travel) insurance

Q18 I will wear disinfectants, masks and gloves on the trip..

Q19 COVID-19 is a very dangerous disease.

Q20 I am worried about the appearance of a new virus.

Q21 I worry that the trip will affect my financial situation.

Q22 I worry that the trip will not provide the value for money.

Q23 I worry that the trip will also involve some unforeseen expenses.

Q24 I am worried that because of COVID-19 and the crisis it has caused, there will be higher costs for food and drinks.

Source: Perić, G., Dramićanin, S., Conić, M. (2021). The impact of Serbian tourists' risk perception on their travel intentions during the COVID-19 pandemic. European Journal of Tourism Research, Vol. 27, 2705 